\title{
Acceleration effect of ionic liquids on polycyclotrimerization of dicyanate esters
}

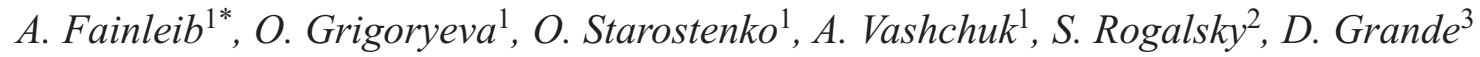 \\ ${ }^{1}$ Institute of Macromolecular Chemistry, National Academy of Sciences of Ukraine, Kharkivske shose 48, 02160 Kyiv, \\ Ukraine \\ ${ }^{2}$ Institute of Bioorganic Chemistry and Petrochemistry, National Academy of Sciences of Ukraine, Kharkivske shose 50, \\ 02160 Kyiv, Ukraine \\ ${ }^{3}$ Institut de Chimie et des Matériaux Paris-Est, UMR 7182 CNRS - Université Paris-Est Créteil Val-de-Marne, 2, \\ rue Henri Dunant, 94320 Thiais, France
}

Received 25 January 2016; accepted in revised form 21 March 2016

\begin{abstract}
The polycyclotrimerization reaction of dicyanate ester of bisphenol E (DCBE) in the presence of varying amounts (from 0.5 to $5 \mathrm{wt} \%$ ) of 1-octyl-3-methylimidazolium tetrafluoroborate ([OMIm] $\left[\mathrm{BF}_{4}\right]$ ) ionic liquid has been investigated using differential scanning calorimetry (DSC) and Fourier transform infrared spectroscopy (FTIR) techniques, after a curing stage at $150^{\circ} \mathrm{C}$ for $6 \mathrm{~h}$. It is noteworthy that an amount of $[\mathrm{OMIm}]\left[\mathrm{BF}_{4}\right]$ as low as $0.5 \mathrm{wt} \%$ accelerates dramatically the thermal curing process leading to the formation of a polycyanurate network. The conversion of DCBE increased with increasing $[\mathrm{OMIm}]\left[\mathrm{BF}_{4}\right]$ content in the temperature range studied. A reaction mechanism associated with the ionic liquid-catalyzed DCBE polycyclotrimerization is newly proposed via the involvement of a $[\mathrm{CN}]^{\delta+}-[\mathrm{OMIm}]^{\delta-}$ complex as a key intermediate.
\end{abstract}

Keywords: polymer synthesis, polycylotrimerization, cyanate ester resins, ionic liquid

\section{Introduction}

Cyanate ester resins (CERs) - also known as polycyanurates (PCNs) - are commonly used in aerospace applications and electronic devices as high temperature polymer matrices. The specific interest in these high performance polymers arises from their unique combination of intrinsic properties, including thermal, fire, radiation and chemical resistance, high tensile moduli (3.1-3.4 GPa) and glass transition temperatures $\left(T_{\mathrm{g}}>250^{\circ} \mathrm{C}\right)$, low dielectric constants $(\varepsilon \sim$ 2.5-3.2), high adhesion to conductor metals and composites as well as low water/moisture adsorption $[1,2]$.

Ionic liquids (ILs) have attracted widespread interest in polymer science, due to their unique properties, such as low melting temperature, incombustibility, electrochemical, and high-temperature stability. They have progressively been used as solvents and substances with catalytic properties $[3,4]$ as well as conductive fillers [5]. Miscellaneous reports on using ILs in polymerization processes have been published [6-12]. For instance, Wu et al. [12] have recently investigated the cationic polymerization of isobutyl vinyl ether in 1-octyl-3-methylimidazolium tetrafluoroborate $\left([\mathrm{OMIm}]\left[\mathrm{BF}_{4}\right]\right)$. It was noticed that the cationic process led to higher monomer conversions in the presence of $[\mathrm{OMIm}]\left[\mathrm{BF}_{4}\right]$. Although the polymerization reaction in $[\mathrm{OMIm}]\left[\mathrm{BF}_{4}\right]$ could not be controlled, due to the presence of $\beta$-proton elimination, the monomer addition experiments confirmed the existence of long-lived species. The results showed that introducing a small amount of 2,6-di-tertiobutyl

${ }^{*}$ Corresponding author, e-mail: fainleib@i.ua

(C) BME-PT 
pyridine into the system might lead to a controlled polymerization. In contrast, reports on ILs involved in crosslinking processes are much scarcer [13].

The curing kinetics of neat CERs has extensively been reported in the literature [14-21]. It is of common knowledge that the polycyclotrimerization of dicyanate esters is rather slow, and it generally requires the presence of a curing catalyst which may be either a Lewis acids or acetylacetonates of $\mathrm{Cu}^{2+}, \mathrm{Co}^{3+}$, $\mathrm{Zn}^{2+}$ and $\mathrm{Mn}^{2+}$ [22], or a chelate in the presence of an active hydrogen-containing co-catalyst (such as nonylphenol), acting as a source of proton. Recently, Throckmorton [23] has examined the effect of ILs on curing of cyanate esters in IL-modified thermosets and their nanocomposites, and interestingly, he concluded that the ionic liquids accelerated the CER curing.

In the present work, we have highlighted the acceleration effect occurring in the polymerization of a dicyanate monomer in the presence of a specific ionic liquid, namely [OMIm] $\left[\mathrm{BF}_{4}\right]$, and for the first time suggested the mechanism of the polycyclotrimerization of cyanate ester in the presence of imidazolium IL. It is worth noting that ILs are thermally stable compounds that is important for the polycyclotrimerization, which is usually carried out at high temperatures up to $230-280^{\circ} \mathrm{C}[1,2]$. The structure of such catalyst systems allows for easier separation, recovery, and recycling from the reaction mixtures [24]. Additionally, introducing ILs into CER frameworks may impart conductivity to the CER-based nanocomposites. ILs could be extracted and potentially used repeatedly; therefore, CER/IL composites could be applied as precursors to porous materials as well.

\section{Experimental}

\subsection{Materials}

1,1'-Bis(4-cyanatophenyl)ethane (dicyanate ester of bisphenol E, DCBE) under the trade name Primaset ${ }^{\mathrm{TM}}$ LECy, was kindly supplied by Lonza Ltd., Switzerland, and was used as received. The following chemicals were used for the synthesis of the 1-octyl-3methylimidazolium tetrafluoroborate ([OMIm] $\left.\left[\mathrm{BF}_{4}\right]\right)$ : 1-methylimidazole, 1-bromooctane, tetrafluoroboric acid $\left(50 \%\right.$ in $\left.\mathrm{H}_{2} \mathrm{O}\right)$, ethyl acetate, hexane, methylene chloride, and sodium sulfate. The chemicals were provided by Fluka and were used as received.

\subsection{Ionic liquid synthesis}

1-octyl-3-methylimidazolium tetrafluoroborate $[\mathrm{OMIm}]\left[\mathrm{BF}_{4}\right]$ was synthesized using the approaches described elsewhere $[25,26]$. The mixture of 1-bromooctane $(27 \mathrm{~g}, 0.14 \mathrm{~mol})$ and 1-methylimidazole (10 g, $0.12 \mathrm{~mol}$ ) was heated at $140^{\circ} \mathrm{C}$ for $2 \mathrm{~h}$ under stirring and argon atmosphere. The viscous liquid of light brown color obtained was cooled to room temperature and washed with ethyl acetate-hexane mixture $(3: 1(\mathrm{v} / \mathrm{v}), 3 \times 100 \mathrm{~mL})$. Residual solvents were removed under reduced pressure, and the obtained product was dissolved in $150 \mathrm{~mL}$ of water. Tetrafluoroboric acid $(25 \mathrm{~mL})$ was added to the solution, followed by stirring for $1 \mathrm{~h}$. The water immiscible layer formed was extracted with methylene chloride $(2 \times 100 \mathrm{~mL})$, and dried overnight with sodium sulfate. The solvent was distilled off, and the resulting ionic liquid was dried under a reduced pressure of $1 \mathrm{mbar}$ at $80^{\circ} \mathrm{C}$ for $12 \mathrm{~h}$. The product yield was equal to $72 \%$. The onset temperature of thermal degradation $\left(T_{\mathrm{d}}\right)$ was equal $343^{\circ} \mathrm{C}$ as determined by thermogravimetric analysis (TGA) under air.

${ }^{1} \mathrm{H}$ NMR $\left(300 \mathrm{MHz}, \mathrm{DMSO}-\mathrm{D}_{6}\right): \delta=0.86(\mathrm{t}, 3 \mathrm{H}$, $\left.\mathrm{CH}_{3}, J=7.2 \mathrm{~Hz}\right), 1.25\left(\mathrm{~m}, 10 \mathrm{H}, \mathrm{CH}_{3}\left(\mathrm{CH}_{2}\right)_{5}\right), 1.78$ (m, 2H, $\mathrm{NCH}_{2} \mathrm{CH}_{2}$ ), 3.85 (s, 3H, $\left.\mathrm{NCH}_{3}\right), 4.16(\mathrm{t}, 2 \mathrm{H}$, $\mathrm{NCH}_{2}, J=7.2 \mathrm{~Hz}$ ), 7.67 (br s, $\left.1 \mathrm{H}, \mathrm{C}_{4}-\mathrm{H}\right), 7.74$ (br $\left.\mathrm{s}, 1 \mathrm{H}, \mathrm{C}_{5}-\mathrm{H}\right), 9.06\left(\mathrm{~s}, 1 \mathrm{H}, \mathrm{C}_{2}-\mathrm{H}\right) .{ }^{19} \mathrm{~F}$ NMR $\left(188 \mathrm{MHz}, \mathrm{DMSO}_{-} \mathrm{D}_{6}\right): \delta=-148.8\left(\mathrm{~s}, 4 \mathrm{~F}, \mathrm{BF}_{4}\right)$.

\subsection{Preparation of $\mathrm{CER} /[\mathrm{OMIm}]\left[\mathrm{BF}_{4}\right]$ samples}

The blends of DCBE monomer with 0.5, 1.0, 2.0, $3.0,4.0$, and $5.0 \mathrm{wt} \%[\mathrm{OMIm}]\left[\mathrm{BF}_{4}\right]$ were stirred at $T \approx 20^{\circ} \mathrm{C}$ for $3 \mathrm{~min}$ to obtain homogeneous mixtures, followed by a heating step at $150^{\circ} \mathrm{C}$ for $6 \mathrm{~h}$.

\subsection{Physico-chemical techniques}

${ }^{1} \mathrm{H}$ NMR and ${ }^{19} \mathrm{~F}$ NMR techniques were used to characterize the ionic liquid. The spectra were recorded with a Varian $(300 \mathrm{MHz})$ NMR spectrometer at $23^{\circ} \mathrm{C}$ using DMSO-D6 as the deuterated solvent.

The thermal stability of the ionic liquid was assessed by TGA under air atmosphere using a TA Instruments TGA Q-50 thermobalance over a temperature range from 25 to $700^{\circ} \mathrm{C}$ at a heating rate of $10^{\circ} \mathrm{C} \cdot \mathrm{min}^{-1}$. Differential scanning calorimetry (DSC) measurements were performed using a Perkin-Elmer DSC-7 under nitrogen atmosphere, in a temperature range 
from 150 to $340^{\circ} \mathrm{C}$ at a heating rate of $10^{\circ} \mathrm{C} \cdot \mathrm{min}^{-1}$. The samples mass was about $6-9 \mathrm{mg}$. The post-curing conversion $\left(\alpha_{\text {post }}\right)$ of cyanate $(\mathrm{O}-\mathrm{C} \equiv \mathrm{N})$ groups from DCBE was calculated from Equation (1) [27]:

$\alpha_{\text {post }}=\left(\alpha_{\mathrm{c}}+\frac{\Delta H_{\mathrm{t}}}{\Delta H_{\mathrm{tot}}}\right) \cdot 100$

where $\alpha_{\mathrm{c}}\left[\left(\Delta H_{\text {tot }}-\Delta H_{\text {post }}\right) / \Delta H_{\text {tot }}\right]$ [28] is the conversion after heating at $150^{\circ} \mathrm{C}$ for $6 \mathrm{~h}, \Delta H_{\mathrm{t}}$ is the reaction enthalpy at time $t, \Delta H_{\text {tot }}$ is the total enthalpy of polycyclotrimerization of DCBE monomer $\left(\Delta H_{\mathrm{tot}}=\right.$ $\left.770 \mathrm{~J}^{-1} \mathrm{~g}^{-1}[29]\right)$, and $\Delta H_{\text {post }}$ is the post-curing enthalpy, which was calculated from the exotherm area of cured sample divided by its mass.

Fourier transform infrared (FTIR) spectra were recorded between 4000 and $600 \mathrm{~cm}^{-1}$ using a Bruker Tensor 37 spectrometer. For each spectrum, 16 consecutive scans with a resolution of $0.6 \mathrm{~cm}^{-1}$ were averaged. All spectra were recorded at room temperature. The monomer conversion was determined from the absorbance variation of the bands with maxima at 2266 and $2235 \mathrm{~cm}^{-1}$, corresponding to the stretching vibrations of the cyanate groups. The stretching band of benzene ring at $1501 \mathrm{~cm}^{-1}$ was used as an internal standard. The conversion $\left(\alpha_{\mathrm{c}}\right)$ of cyanate groups after heating at $150^{\circ} \mathrm{C}$ for $6 \mathrm{~h}$ was calculated from Equation (2):

$\alpha_{\mathrm{c}}=1-\frac{\frac{A_{(t) 2266-2235}}{A_{(0) 2266-2235}}}{\frac{A_{(t) 1501}}{A_{(0) 1501}}} \cdot 100$

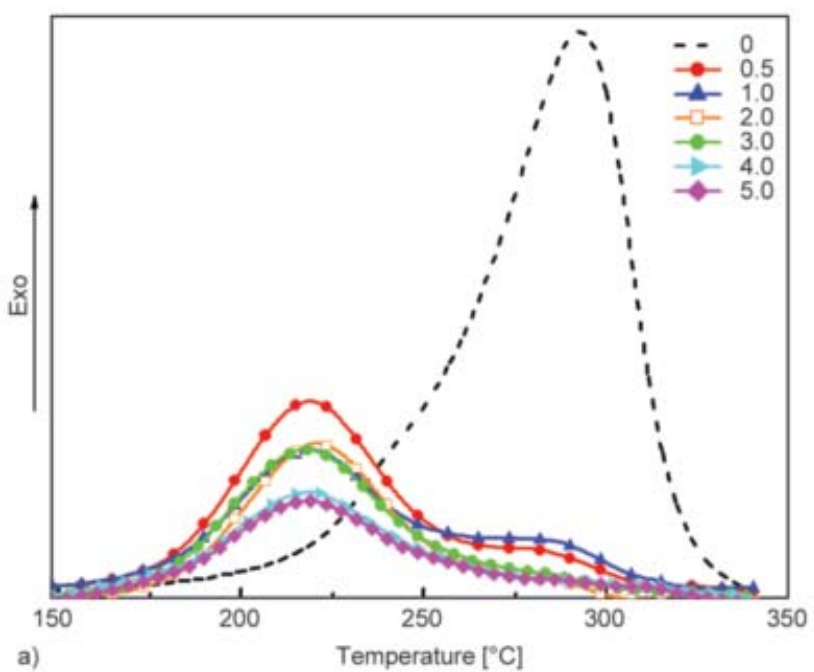

where $A_{(\mathrm{t}) 2266-2235}$ is the area under absorption bands of $\mathrm{O}-\mathrm{C} \equiv \mathrm{N}$ groups at time $t, A_{(\mathrm{t}) 1501}$ is the area under absorption band of benzene ring at time $(t)$, and $A_{(0)}$ is the area under absorption bands of the corresponding groups in initial DCBE monomer.

\section{Results and discussion}

In the first stage the mixtures of DCBE monomer with different amounts of ionic liquid [OMIm] $\left[\mathrm{BF}_{4}\right]$ were heated at $150^{\circ} \mathrm{C}$ for $6 \mathrm{~h}$. In the presence of a catalyst, one such curing step permitted to attain a gel point [30].

\subsection{DSC analysis}

Figure 1a exhibits the DSC thermograms for neat CER and CER/[OMIm] $\left[\mathrm{BF}_{4}\right]$ samples of different compositions cured at $150^{\circ} \mathrm{C}$ for $6 \mathrm{~h}$, and their main thermal characteristics are summarized in Table 1. For the neat CER sample, the exotherm maximum is associated with a temperature of post-curing $\left(T_{\mathrm{p} 1}\right)$ equal to $294^{\circ} \mathrm{C}$ with some weak shoulder at $\sim 239^{\circ} \mathrm{C}$. The shoulder may be attributed to the formation of the intermediate linear CER dimers, trimers and potentially other higher even-mers [31]. The CER/[OMIm] $\left[\mathrm{BF}_{4}\right]$ samples display bimodal curing profiles with distinct exothermic peaks corresponding to CER post-curing process at the selected heating rate $\left(10^{\circ} \mathrm{C} \cdot \mathrm{min}^{-1}\right)$. For the $\mathrm{CER} /[\mathrm{OMIm}]\left[\mathrm{BF}_{4}\right]$ specimens, $T_{\mathrm{p} 1}$ was shifted toward much lower temperatures, i.e. $218-221^{\circ} \mathrm{C}$ (Table 1). This fact attested that, in the presence of $[\mathrm{OMIm}]\left[\mathrm{BF}_{4}\right]$, the polycyclotrimerization of DCBE

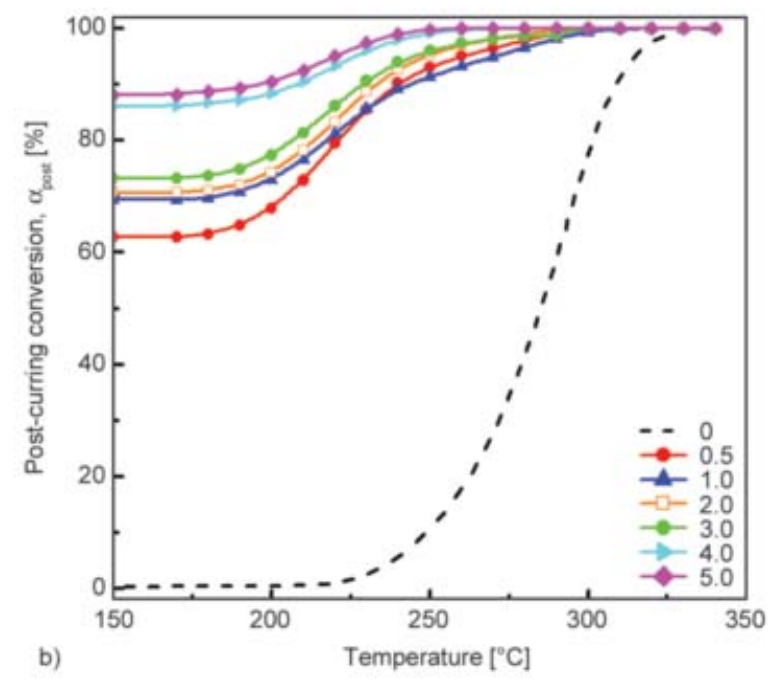

Figure 1. (a) DSC thermograms and (b) temperature dependence of post-curing conversion for CER samples with different $[\mathrm{OMIm}]\left[\mathrm{BF}_{4}\right]$ contents 
Table 1. Thermal characteristics of CER/[OMIm] $\left[\mathrm{BF}_{4}\right]$ samples cured at $150^{\circ} \mathrm{C}$ for $6 \mathrm{~h}$ as determined by DSC

\begin{tabular}{|c|c|c|c|c|c|c|c|}
\hline \multirow{2}{*}{$\begin{array}{c}{[\mathrm{OMIm}]\left[\mathrm{BF}_{4}\right] \text { content }} \\
{[\mathrm{wt} \%]}\end{array}$} & \multicolumn{3}{|c|}{$\begin{array}{c}\text { Post-curing interval } \\
{\left[{ }^{\circ} \mathbf{C}\right]}\end{array}$} & \multirow{2}{*}{$\begin{array}{l}T_{\mathrm{p} 1}{ }^{\mathrm{b}} \\
{\left[{ }^{\circ} \mathrm{C}\right]}\end{array}$} & \multirow{2}{*}{$\begin{array}{l}T_{\mathrm{p} 2}{ }^{\mathrm{c}} \\
{\left[{ }^{\circ} \mathrm{C}\right]}\end{array}$} & \multirow{2}{*}{$\begin{array}{l}\Delta \boldsymbol{H}_{\text {post }}{ }^{\mathrm{d}} \\
{\left[\mathbf{J} \cdot \mathrm{g}^{-1}\right]}\end{array}$} & \multirow{2}{*}{$\begin{aligned} \Delta \boldsymbol{H}_{\mathrm{c}}{ }^{\mathrm{e}} \\
{\left[\mathrm{J} \cdot \mathrm{g}^{-1}\right] }\end{aligned}$} \\
\hline & $T_{\text {onset }}$ & $T_{\text {end }}$ & $\Delta T^{\mathrm{a}}$ & & & & \\
\hline 0.0 & 160 & 339 & 179 & 294 & - & 755 & 15 \\
\hline 0.5 & 154 & 319 & 165 & 219 & 280 & 296 & 474 \\
\hline 1.0 & 156 & 324 & 168 & 218 & 279 & 233 & 537 \\
\hline 2.0 & 156 & 320 & 164 & 221 & 280 & 223 & 544 \\
\hline 3.0 & 155 & 318 & 163 & 218 & 281 & 203 & 567 \\
\hline 4.0 & 154 & 320 & 166 & 220 & 282 & 120 & 650 \\
\hline 5.0 & 153 & 318 & 165 & 218 & 282 & 114 & 656 \\
\hline
\end{tabular}

aPost-curing temperature interval: $\Delta T=T_{\text {end }}-T_{\text {onset }}$

${ }^{b}$ Peak temperature of post-curing associated with first endotherm maximum

'Peak temperature of post-curing associated with second endotherm maximum

${ }^{d}$ Post-curing enthalpy under selected conditions (from 150 to $340^{\circ} \mathrm{C}$ at $10^{\circ} \mathrm{C} \cdot \mathrm{min}^{-1}$ )

${ }^{\mathrm{e}}$ Curing enthalpy after heating at $150^{\circ} \mathrm{C}$ for $6 \mathrm{~h}: \Delta H_{\mathrm{c}}=\Delta H_{\text {tot }}-\Delta H_{\text {post }}, \Delta H_{\text {tot }}=770 \mathrm{~J} \cdot \mathrm{g}^{-1}$ [30]

mostly occurred at lower temperatures. Yet, in the latter case, it should be noted that weak peaks $\left(T_{\mathrm{p} 2}\right)$ appeared around $279-282^{\circ} \mathrm{C}$, namely at a temperature similar to that of pure DCBE polymerization. One could suppose that the first exotherm maximum corresponded to the curing reaction catalyzed by $[\mathrm{OMIm}]\left[\mathrm{BF}_{4}\right]$, while the second peak was attributed to a higher temperature thermal curing without catalyst participation.

Table 1 clearly shows that the reaction rate of CER curing was enhanced by the presence of $[\mathrm{OMIm}]\left[\mathrm{BF}_{4}\right]$. It is noteworthy that loading of $[\mathrm{OMIm}]\left[\mathrm{BF}_{4}\right]$ was associated with a substantial narrowing the post-curing temperature interval from $179^{\circ} \mathrm{C}$ for neat CER to $163-168^{\circ} \mathrm{C}$ for $\mathrm{CER} /[\mathrm{OMIm}]\left[\mathrm{BF}_{4}\right]$ samples. Moreover, the enthalpy of post-curing process $\left(\Delta H_{\text {post }}\right)$ for pure DCDE was equal to $755 \mathrm{~J} \cdot \mathrm{g}^{-1}$. According to literature [29], the total enthalpy of polycyclotrimerization of DCBE monomer $\left(\Delta H_{\text {tot }}\right)$ was equal to $770 \mathrm{~J} \cdot \mathrm{g}^{-1}$. Therefore, one could conclude that the polymerization of neat DCBE practically did not occur after the $6 \mathrm{~h}$-curing stage at $150^{\circ} \mathrm{C}$. In sharp contrast, $\Delta H_{\text {post }}$ for DCBE post-polycyclotrimerization in the IL-containing samples dramatically decreased with increasing $[\mathrm{OMIm}]\left[\mathrm{BF}_{4}\right]$ contents, so in turn the curing enthalpy after the curing stage at $150^{\circ} \mathrm{C}$ for $6 \mathrm{~h}\left(\Delta H_{\mathrm{c}}\right)$ increased accordingly.

Figure $1 \mathrm{~b}$ displays the temperature dependence of post-curing conversion values $\left(\alpha_{\text {post }}\right)$ for neat CER and $\mathrm{CER} /[\mathrm{OMIm}]\left[\mathrm{BF}_{4}\right]$ samples. As stated above, the polymerization of DCBE monomer hardly occurred during thermal heating at $150^{\circ} \mathrm{C}$ for $6 \mathrm{~h}$, thus the corresponding curve started around $2 \%$ conversion. When pure $\mathrm{DCBE}$ was post-cured from 150 to $340^{\circ} \mathrm{C}$ with a heating rate of $10^{\circ} \mathrm{C} \mathrm{min}{ }^{-1}$, an induction period was found to last around $7.5 \mathrm{~min}$ before reaching $225^{\circ} \mathrm{C}$, i.e. the temperature from which $\alpha_{\text {post }}$ appeared to sharply increase up to $100 \%$ conversion. Contrarily, the $\mathrm{O}-\mathrm{C} \equiv \mathrm{N}$ conversion $\left(\alpha_{\mathrm{c}}\right)$ in the CER/ [OMIm] $\left[\mathrm{BF}_{4}\right]$ samples after heating at $150^{\circ} \mathrm{C}$ for $6 \mathrm{~h}$ reached values as high as $62-85 \%$, depending on the [OMIm] $]\left[\mathrm{BF}_{4}\right]$ content (Table 2). Notably, complete conversion was not reached because of the low curing temperature $\left(150^{\circ} \mathrm{C}\right)$ as far as the final curing temperature should be equal to $230-270^{\circ} \mathrm{C}$, and even higher $[1,2]$. When heating from 150 to $340^{\circ} \mathrm{C}$, the DCBE conversion values $\left(\alpha_{\text {post }}\right)$ further increased gradually to attain completion. In summary, the higher the $[\mathrm{OMIm}]\left[\mathrm{BF}_{4}\right]$ content, the higher the $\mathrm{O}-\mathrm{C} \equiv \mathrm{N}$ conversion $\left(\alpha_{c}\right)$ reached after heating at $150^{\circ} \mathrm{C}$ for $6 \mathrm{~h}$, and the shorter the time to reach complete conversion during post-curing process.

Table 2. Conversion values $\left(\alpha_{\mathrm{c}}\right)$ for $\mathrm{CER} /[\mathrm{OMIm}]\left[\mathrm{BF}_{4}\right]$ samples after heating at $150{ }^{\circ} \mathrm{C}$ for $6 \mathrm{~h}$

\begin{tabular}{|c|c|c|}
\hline \multirow{2}{*}{$\begin{array}{c}\text { [OMIm] } \\
{\left[\mathbf{B} \mathbf{B F}_{4}\right] \text { content }}\end{array}$} & \multicolumn{2}{|c|}{$\begin{array}{c}\boldsymbol{\alpha}_{\mathbf{c}} \\
{[\%]}\end{array}$} \\
\cline { 2 - 3 } & $\mathbf{D S C}^{\mathbf{a}}$ & FTIR $^{\mathbf{b}}$ \\
\hline 0.0 & 2 & 1 \\
\hline 0.5 & 62 & 59 \\
\hline 1.0 & 69 & 65 \\
\hline 2.0 & 71 & 76 \\
\hline 3.0 & 74 & 77 \\
\hline 4.0 & 84 & 86 \\
\hline 5.0 & 85 & 87 \\
\hline
\end{tabular}

${ }^{a}$ The experimental error on values determined by DSC was estimated to be equal to $1 \%$

${ }^{\mathrm{b}}$ The experimental error on values determined by FTIR was estimated to be equal to $2 \%$ 


\subsection{FTIR analysis}

The peculiarities of DCBE polycyclotrimerization in the absence and in the presence of $[\mathrm{OMIm}]\left[\mathrm{BF}_{4}\right]$ were also investigated using FTIR. Figure 2 shows the FTIR absorption spectra for uncured DCBE monomer (curve 0 ), neat CER (curve $0_{\mathrm{T}}$ ), and CER/[OMIm] $\left[\mathrm{BF}_{4}\right]$ samples (curves $0.5_{\mathrm{T}}-5.0_{\mathrm{T}}$ ) after heating at $150^{\circ} \mathrm{C}$ for $6 \mathrm{~h}$. For neat CER, no visible changes in the intensity of the bands of cyanate groups at 2266$2235 \mathrm{~cm}^{-1}$ were observed, and a very low conversion of DCBE could be suggested on the basis of the appearance of small bands at 1563 and $1366 \mathrm{~cm}^{-1}$, corresponding to $\mathrm{C}=\mathrm{N}-\mathrm{C}$ groups and $\mathrm{N}-\mathrm{C}-\mathrm{O}$ groups of cyanurate cycles, respectively. In contrast, concerning $\mathrm{CER} /[\mathrm{OMIm}]\left[\mathrm{BF}_{4}\right]$ samples, the intensity of the bands at 2266-2235 $\mathrm{cm}^{-1}$ decreased, and bands clearly appeared at 1563 and $1366 \mathrm{~cm}^{-1}$, thus evidencing the formation of polycyanurate crosslinked structures. This conclusion was in a good agreement with the DSC data discussed above. The conversion values $\left(\alpha_{\mathrm{c}}\right)$ of $\mathrm{O}-\mathrm{C} \equiv \mathrm{N}$ groups associated with the different $[\mathrm{OMIm}]\left[\mathrm{BF}_{4}\right]$ contents was calculated using FTIR data, and both sets of values obtained from FTIR and DSC data matched pretty well (see Table 2).

Both FTIR and DSC results clearly evidenced an acceleration effect of $[\mathrm{OMIm}]\left[\mathrm{BF}_{4}\right]$ on the CER formation during curing process at $150^{\circ} \mathrm{C}$ for $6 \mathrm{~h}$. Inter- estingly, the catalytic effect was already noticeable at the lowest content of $[\mathrm{OMIm}]\left[\mathrm{BF}_{4}\right]$ investigated, i.e. $0.5 \mathrm{wt} \%$. This could be attributed to the presence of an acid center in the ring of the [OMIm] cation, which might accelerate the polycyclotrimerization of the dicyanate monomer.

\subsection{Proposed mechanism of the $[\mathrm{OMIm}]\left[\mathrm{BF}_{4}\right]$-catalyzed cyclotrimerization of DCBE}

It has been well investigated that Lewis acids, such as $\mathrm{TiCl}_{4}$, could be used as catalysts for polycyclotrimerization of dicyanate esters [32]. Martin and coworkers $[33,34]$ reported the appearance of bands around $2300 \mathrm{~cm}^{-1}$ when dicyanates were treated with an excess of Lewis acid. A strong band at $2320 \mathrm{~cm}^{-1}$ indeed appeared upon addition of $1-5$ equiv. of $\mathrm{TiCl}_{4}$ to bisphenol A dicyanate ester; no 'free' cyanate was detectable in these cases [32]. The band at $2320 \mathrm{~cm}^{-1}$, attributed to a cyanate-catalyst complex, was formed rapidly on mixing before gradually disappearing at the end of the reaction. Therefore, the band around $2300-2320 \mathrm{~cm}^{-1}$ was ascribed to a simple cyanateLewis acid complex [32-34].

Likewise, in our investigation, we proposed a mechanism involving a cyanate-ionic liquid complex. Indeed, the appearance of a shoulder at $2330 \mathrm{~cm}^{-1}$ in
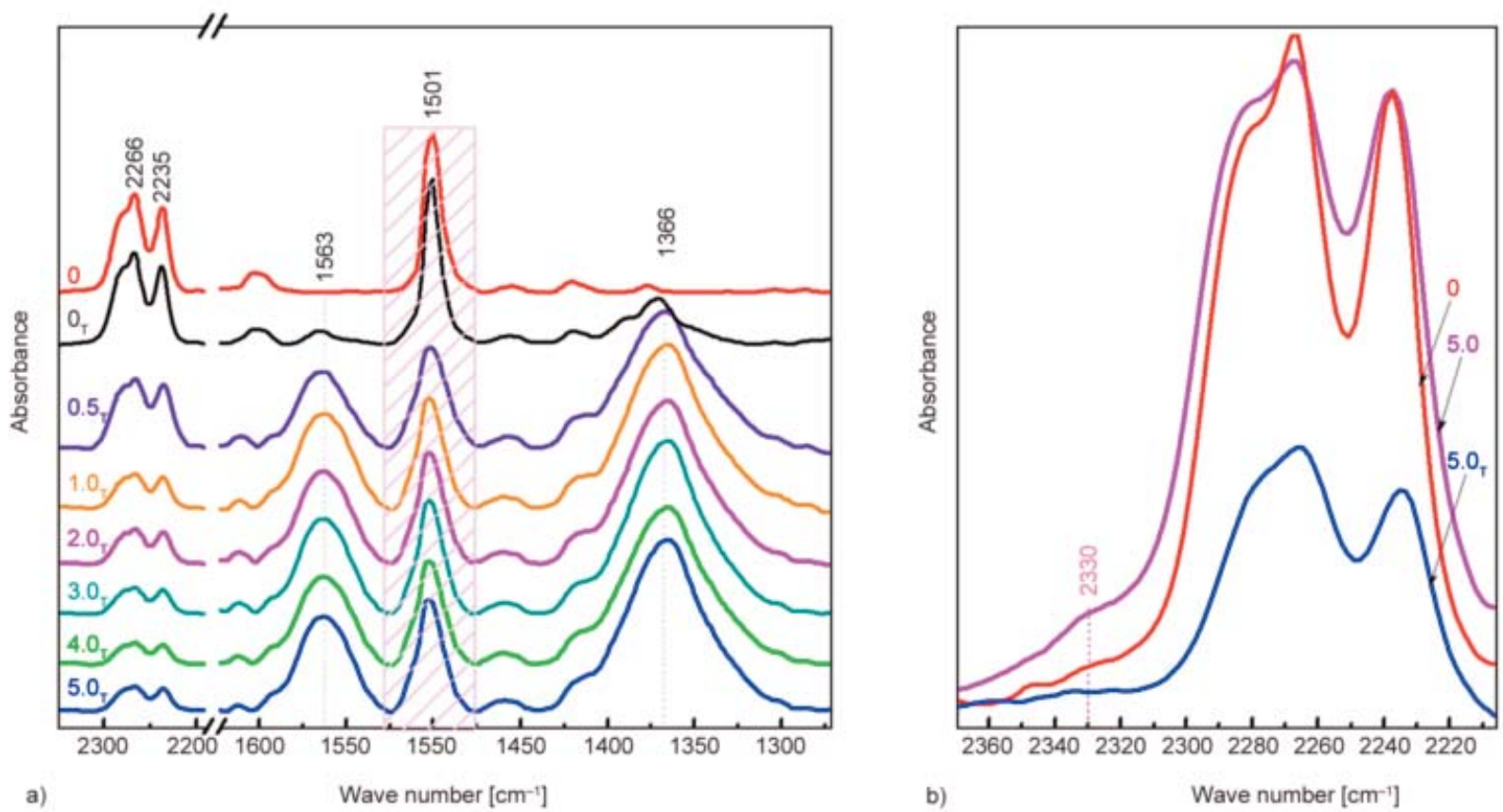

Figure 2. FTIR spectra of: (a) DCBE monomer (curve 0) and CER samples with different [OMIm] $\left[\mathrm{BF}_{4}\right]$ contents after heating at $150{ }^{\circ} \mathrm{C}$ for $6 \mathrm{~h}$ (curves $0_{\mathrm{T}}-5.0_{\mathrm{T}}$, the number indicating the IL content); (b) uncured DCBE (curve 0 ) and $\mathrm{CER} /[\mathrm{OMIm}]\left[\mathrm{BF}_{4}\right]$ sample $\left(95 / 5 \mathrm{wt} \%\right.$ ) before (curve 5.0) and after (curve $5.0_{\mathrm{T}}$ ) the same heating stage in the spectral zone of $2370-2200 \mathrm{~cm}^{-1}$ 
the FTIR spectra after mixing DCBE with $5 \mathrm{wt} \%$ of [OMIm] $\left[\mathrm{BF}_{4}\right]$ was observed in Figure $2 b$ (curve 5.0). After heating the mixture at $150^{\circ} \mathrm{C}$ for $6 \mathrm{~h}$ and reaching high conversion of cyanate groups, this shoulder disappeared (curve $5.0_{\mathrm{T}}$ ). We proposed a possible mechanism for the DCBE/[OMIm] $\left[\mathrm{BF}_{4}\right]$ system in Figure 3. First, a pseudo-nitrillium ion $\mathbf{2}$ was formed when mixing dicyanate $\mathbf{1}$ with $[\mathrm{OMIm}]\left[\mathrm{BF}_{4}\right]$ via the involvement of a $[\mathrm{CN}]^{\delta+}-[\mathrm{OMIm}]^{\delta-}$ complex whose characteristic FTIR absorption band could be assigned to the shoulder at $2330 \mathrm{~cm}^{-1}$. This cyanateionic liquid complex was then attacked by a 'free' cyanate monomer $\mathbf{1}$, thus leading to the formation of a nitrillium ion 3. The latter was attacked by a 'free' dicyanate molecule $\mathbf{1}$ with formation of a nitrillium ion 4, which was transformed into an acyclic trimer 5 with $[\mathrm{OMIm}]\left[\mathrm{BF}_{4}\right]$ release, and finally into a cyclotrimer (cyanurate) 6 . Taking in account the existence of an acid center in the ring of 1-octyl-3methylimidazolium cation (i.e., $\mathrm{C}-\mathrm{H}$ bond in position 2 imparts slight acidity); we could suppose that this center indeed catalyzed the cyclotrimerization reaction of DCBE. It has to be noted here that a small shoulder at $2330 \mathrm{~cm}^{-1}$ is also observed in the FTIR spectrum of the DCBE. It is known that phenolic groups catalyze polycyclotrimerization of CER and

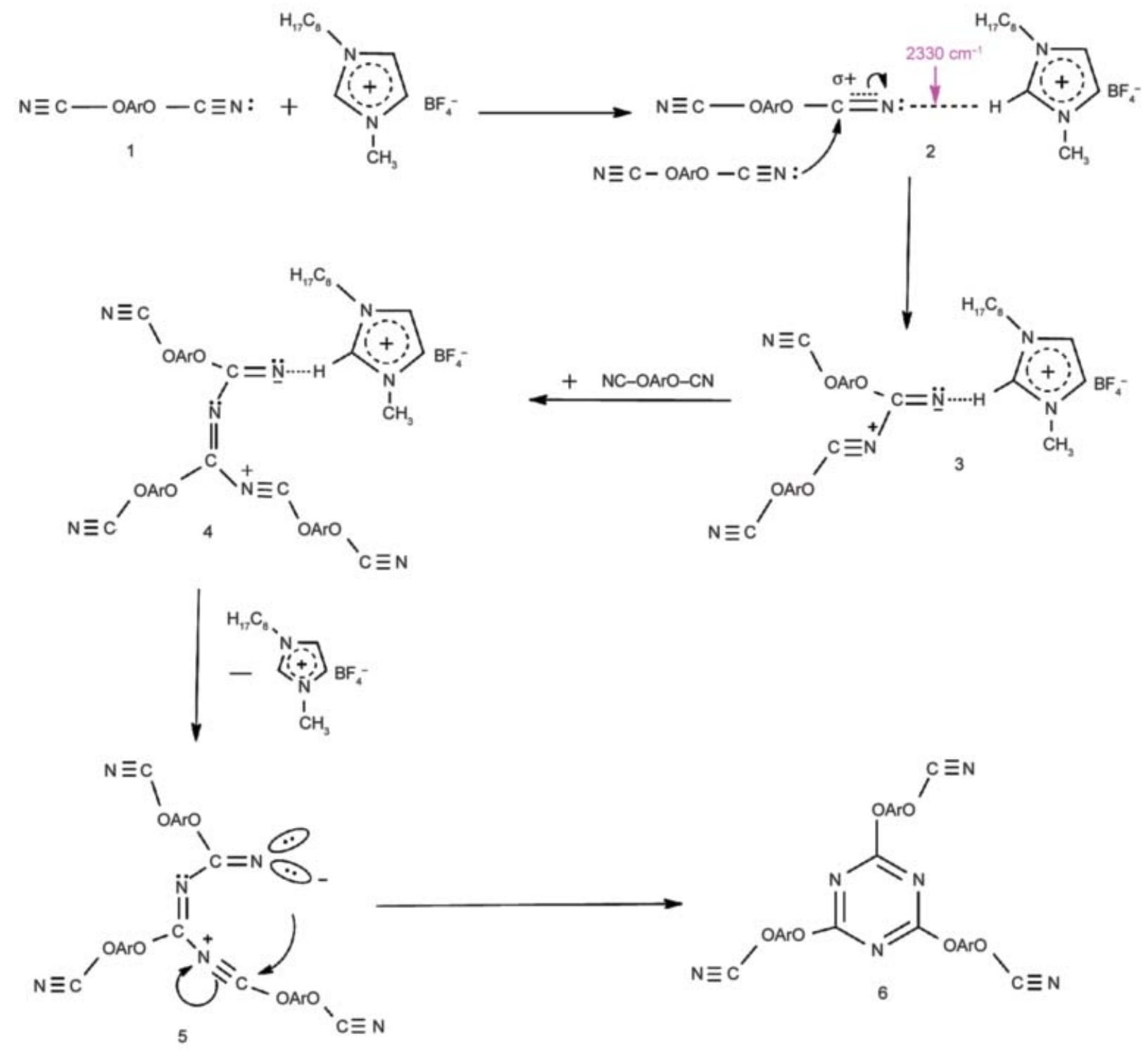

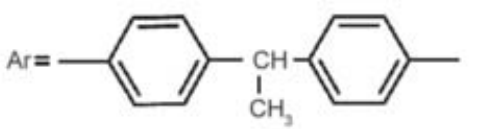

Figure 3. Proposed mechanism for the $[\mathrm{OMIm}]\left[\mathrm{BF}_{4}\right]$-catalyzed cyclotrimerization of DCBE 
it occurs also through formation of the intermediate structure, which disappear after formation of triazine cycle and reclaiming phenol [1]. So the traces of bisphenol E, left after DCBE synthesis, could form the dimer structures with cyanate ester and this complex may be also characterized by the shoulder at $2330 \mathrm{~cm}^{-1}$ in FTIR spectrum of neat cyanate ester.

\section{Conclusions}

The $[\mathrm{OMIm}]\left[\mathrm{BF}_{4}\right]$-catalyzed polycyclotrimerization of DCBE was investigated through DSC and FTIR analyses. A dramatic influence of the ionic liquid on CER curing was demonstrated. For samples containing $[\mathrm{OMIm}]\left[\mathrm{BF}_{4}\right]$, polycyclotrimerization of $\mathrm{DCBE}$ took place even at the heating stage at $150^{\circ} \mathrm{C}$, while for pure $\mathrm{DCBE}$ polycyclotrimerization practically did not occur. The conversion of DCBE increased with increasing [OMIm] $\left[\mathrm{BF}_{4}\right]$ contents in the temperature range studied. A plausible mechanism based on the formation of a $[\mathrm{CN}]^{\delta+}-[\mathrm{OMIm}]^{\delta-}$ complex was proposed to account for the acceleration effect of the ionic liquid on the curing process associated with CERs. We assume that one such catalytic effect of imidazoliumbased ILs will take place for any dicyanate monomer. The effect of other IL types on kinetics of polycyclotrimerization of dicyanate esters has to be further studied.

It should be emphasized that $[\mathrm{OMIm}]\left[\mathrm{BF}_{4}\right]$ displayed a catalytic activity in the absence of any additional organic solvent or co-catalyst. Interestingly, the ionic liquid is not destroyed during the CER synthesis.

\section{Acknowledgements}

The authors gratefully acknowledge the National Academy of Sciences of Ukraine (NASU) and the 'Centre National de la Recherche Scientifique' (CNRS) of France for partial financial support through bilateral cooperation project No. 26199.

\section{References}

[1] Hamerton I.: Chemistry and technology of cyanate ester resins. Chapman and Hall, Glasgow (1994).

[2] Fainleib A.: Thermostable polycyanurates: Synthesis, modification, structure and properties. Nova Science Publishers, New York (2010).

[3] Wang Y., Li H., Wang C., Jiang H.: Ionic liquids as catalytic green solvents for cracking reactions. Chemical Communications, 17, 1938-1939 (2004).

DOI: 10.1039/B402524E
[4] Olivier-Bourbigou H., Magna L., Morvan D.: Ionic liquids and catalysis: Recent progress from knowledge to applications. Applied Catalysis A: General, 373, 1-56 (2010).

DOI: $10.1016 /$ j.apcata.2009.10.008

[5] Ohno H., Yoshizawa M., Ogihara W.: Development of new class of ion conductive polymers based on ionic liquids. Electrochimica Acta, 50, 255-261 (2004).

DOI: $10.1016 /$ j.electacta.2004.01.091

[6] Wasserscheid P., Welton T.: Ionic liquids in synthesis. Wiley, Weinheim (2002).

[7] Holbrey J. D., Chen J., Turner M. B., Swatloski R. P., Spear S. K., Rogers R. D.: Applying ionic liquids for controlled processing of polymer materials. in 'Ionic liquids in polymer systems' (eds.: Brazel C. S., Rogers R. D.) ACS Symposium Series, Washington, Vol 913, 71-87 (2005).

DOI: 10.1021/bk-2005-0913.ch005

[8] Pârvulescu V. I., Hardacre C.: Catalysis in ionic liquids. Chemical Reviews, 107, 2615-2665 (2007).

DOI: $10.1021 / \mathrm{cr} 050948 \mathrm{~h}$

[9] Strehmel V., Berdzinski S., Ehrentraut L., Faßbender C., Horst J., Leeb E., Liepert J., Ruby M-P., Senkowski V., Straßburg P., Wenda A., Strehmel C.: Application of ionic liquids in synthesis of polymeric binders for coatings. Progress in Organic Coatings, 89, 297-313 (2015). DOI: $10.1016 /$ j.porgcoat.2015.07.025

[10] Stejskal J., Dybal J., Trchová M.: The material combining conducting polymer and ionic liquid: Hydrogen bonding interactions between polyaniline and imidazolium salt. Synthetic Metals, 197, 168-174 (2014).

DOI: $10.1016 /$ j.synthmet.2014.09.002

[11] Trchová M., Šeděnková I., Morávková Z., Stejskal J.: Conducting polymer and ionic liquid: Improved thermal stability of the material - A spectroscopic study. Polymer Degradation and Stability, 109, 27-32 (2014). DOI: 10.1016/j.polymdegradstab.2014.06.012

[12] Wu Y-B., Han L., Zhang X-G., Mao J., Gong L-F., Guo W-L., Gu K., Li S-X.: Cationic polymerization of isobutyl vinyl ether in an imidazole-based ionic liquid: Characteristics and mechanism. Polymer Chemistry, 6, 25602568 (2015).

DOI: $10.1039 / \mathrm{C} 4 \mathrm{PY} 01784 \mathrm{~F}$

[13] Snedden P., Cooper A. I., Khimyak Y. Z., Scott K., Winterton N.: Cross-linked polymers in ionic liquids: Ionic liquids as porogens. in 'Ionic liquids in polymer systems' (eds.: Brazel C. S., Rogers R. D.) ACS Symposium Series, Washington, Vol 913, 133-147 (2005).

DOI: $10.1021 / \mathrm{bk}-2005-0913 . c h 009$

[14] Osei-Owusu A., Martin G. C., Gotro J. T.: Analysis of the curing behavior of cyanate ester resin systems. Polymer Engineering and Science, 31, 1604-1609 (1991). DOI: $10.1002 /$ pen.760312208

[15] Osei-Owusu A., Martin G. C., Gotro J. T.: Catalysis and kinetics of cyclotrimerization of cyanate ester resin systems. Polymer Engineering and Science, 32, 535-541 (1992).

DOI: $10.1002 /$ pen.760320805 
[16] Wu S. J., Mi F. L.: Cure kinetics of a cyanate ester blended with poly(phenylene oxide). Polymer International, 55, 1296-1303 (2006).

DOI: $10.1002 /$ pi.2083

[17] Gómez C. M., Recalde I. B., Mondragon I.: Kinetic parameters of a cyanate ester resin catalyzed with different proportions of nonylphenol and cobalt acetylacetonate catalyst. European Polymer Journal, 41, 2734 2741 (2005).

DOI: 10.1016/j.eurpolymj.2005.05.005

[18] Simon S. L., Gillham K. J.: Cure kinetics of a thermosetting liquid dicyanate ester monomer/high- $T_{\mathrm{g}}$ polycyanurate material. Journal of Applied Polymer Science, 47, 461-485 (1993).

DOI: 10.1002/app.1993.070470308

[19] Li W., Liang G., Xin W.: Triazine reaction of cyanate ester resin systems catalyzed by organic tin compound: Kinetics and mechanism. Polymer International, 53, 869876 (2004).

DOI: $10.1002 /$ pi.1446

[20] Fainleib A., Bardash L., Boiteux G.: Catalytic effect of carbon nanotubes on polymerization of cyanate ester resins. Express Polymer Letters, 3, 477-482 (2009). DOI: $10.3144 /$ expresspolymlett.2009.59

[21] Bershtein V. A., Fainleib A. M., Pissis P., Bei I. M., Dalmas F., Egorova L. M., Gomza Y. P., Kripotou S., Maroulos P., Yakushev P. N.: Polycyanurate-organically modified montmorillonite nanocomposites: Structure-dynamics-properties relationships. Journal of Macromolecular Science Part B: Physics, 47, 555-575 (2008). DOI: $10.1080 / 00222340801955545$

[22] Li Q. F., Lu K., Yang Q. Q., Jin R.: The effect of different metallic catalysts on the coreaction of cyanate/epoxy. Journal of Applied Polymer Science, 100, 2293-2302 (2006).

DOI: $10.1002 /$ app.22882

[23] Throckmorton J. A.: Ionic liquid-modified thermosets and their nanocomposites: Dispersion, exfoliation, degradation, and cure. PhD dissertation, Drexel University (2015).

[24] Valkenberg M. H., de Casto C., Hölderich W. F.: Immobilisation of ionic liquids on solid supports. Green Chemistry, 4, 88-93 (2002).

DOI: $10.1039 / \mathrm{B} 107946 \mathrm{H}$

[25] Dzyuba S. V., Bartsch R. A.: Efficient synthesis of 1alkyl(aralkyl)-3-methyl(ethyl)imidazolium halides: Precursors for room-temperature ionic liquids. Journal of Heterocyclic Chemistry, 38, 265-268 (2001).

DOI: $10.1002 /$ jhet.5570380139
[26] Ennis E., Handy T. S.: Facile route to C2-substituted imidazolium ionic liquids. Molecules, 14, 2235-2245 (2009).

DOI: $10.3390 /$ molecules14062235

[27] Li J., Chen P., Ma Z., Ma K., Wang B.: Reaction kinetics and thermal properties of cyanate ester-cured epoxy resin with phenolphthalein poly(ether ketone). Journal of Applied Polymer Science, 111, 2590-2596 (2009). DOI: 10.1002/app.29264

[28] Zhao L., Hu X.: A variable reaction order model for prediction of curing kinetics of thermosetting polymers. Polymer, 48, 6125-6133 (2007).

DOI: 10.1016/j.polymer.2007.07.067

[29] Reams J. T., Guenthner A. J., Lamison K. R., Vij V., Lubin L. M., Mabry J. M.: Effect of chemical structure and network formation on physical properties of di(cyanate ester) thermosets. ACS Applied Materials and Interfaces, 4, 527-535 (2012).

DOI: $10.1021 / \mathrm{am} 201413 \mathrm{t}$

[30] Fainleib A., Gusakova K., Grigoryeva O., Starostenko O., Grande D.: Synthesis, morphology, and thermal stability of nanoporous cyanate ester resins obtained upon controlled monomer conversion. European Polymer Journal, 73, 94-104 (2015).

DOI: 10.1016/j.eurpolymj.2015.10.009

[31] Kasehagen L. J., Macosko C. W.: Structure development in cyanate ester polymerization. Polymer International, 44, 237-247 (1997).

DOI: 10.1002/(SICI)1097-0126(199711)44:3<237::AIDPI868>3.0.CO;2-L

[32] Cunningham I. D., Brownhill A., Hamerton I., Howlin B.: Kinetics and mechanism of the titanium tetrachloride-catalysed cyclotrimerisation of aryl cyanates. Journal of the Chemical Society, Perkin Transactions 2, 9, 1937-1943 (1994).

DOI: $10.1039 / \mathrm{P} 29940001937$

[33] Martin D., Weise A.: Cyansäureester, XIV. Komplexe von Cyansäure-arylestern mit Lewis-säuren und ihre Alkylierung (in German). Chemische Berichte, 100, 3747-3755 (1967).

DOI: 10.1002/cber.19671001133

[34] Martin D., Bauerand M., Pankratov V. A.: Cyclotrimerisation of cyano-compounds into 1,3,5-triazines. Russian Chemical Reviews, 47, 975-990 (1978). DOI: 10.1070/RC1978v047n10ABEH002288 